\title{
ANALISIS MODALITAS TUTURAN BASUKI CAHAYA PURNAMA DALAM WACANA KALIJODO
}

\section{MODALITY ANALYSIS OF BASUKI CAHAYA PURNAMA'S SPEECH ON KALIJODO DISCOURSE}

\author{
Yusep Ahmadi F. \\ STKIP Siliwangi Bandung \\ Program Studi Pendidikan Bahasa dan Sastra Indonesia \\ Jalan Terusan Jendral Sudirman, Cimahi 40526 \\ Telepon: 081320668124, Pos-el yyusepp@yahoo.com
}

\begin{abstract}
Abstrak
Makalah ini membahas modalitas tuturan Jakarta Basuki Cahaya Purnama dalam wacana Kalijodo. Masalah dalam penelitian ini adalah bentuk modalitas tuturan, sikap, dan representasi Gubernur Jakarta, Basuki Cahaya Purnama, dalam wacana Kalijodo. Teori yang digunakan dalam penelitian ini adalah teori modalitas menurut Alwi (1992) dan Fairclough (Santoso, 2012). Metode yang dilakukan dalam penelitian ini adalah metode kualitatif-deskriptif, yakni melakukan pemaparan dan penilaian terhadap data kebahasaan melalui teori modalitas sebagai alat analisis. Hasil analisis menunjukkan terdapat sembilan bentuk modalitas deontik bermakna perintah dan/atau sembilan modalitas relasional-perintah. Jumlah modalitas tersebut sangat dominan dibanding dengan jumlah modalitas epistemik bermakna kepastian empat buah, modalitas dinamik kesanggupan satu buah, modalitas epistemik keteramalan satu buah, dan modalitas intensional permintaan satu buah. Hal tersebut merepresentasikan sikap Basuki Cahaya Purnama yang sangat memiliki kuasa. Selain itu, temuan modalitas deontik-perintah atau relasional-perintah yang dominan ditambah dengan modalitas epistemik kepastian diurutan kedua jumlahnya menunjukkan bahwa Ahok dalam menanggulangi kasus Kalijodo dengan pendekatan perintah yang tegas tanpa keraguan.
\end{abstract}

Kata Kunci: Analisis Modalitas, Tuturan Basuki Cahaya Purnama, Wacana Kalijodo

\section{Abstract}

This paper discusses speech modality uttered by the Governor of Jakarta Basuki Cahaya Purnama on Kalijodo discourse. The problem in this research is the form of speech modality, attitude, and representation of Jakarta Governor, Basuki Cahaya Purnama, on Kalijodo discourse. This research applies the theory of modality from Alwi (1992) and Fairclough (Santoso, 2012). The method used in this research is qualitative-descriptive method, by presenting and assessing the exposures of linguistic data through modality theory as a device analysis. The analysis shows there are nine forms of deontic modalities with command significancy and/or nine forms of relational-command modalities. The aggregate of such modality is more dominant than the amount of epistemic modality with certainty meaning as many as four, one modality of dynamic ability, one modality of predictability epistemic, and one modality of intentional demand. This represents that Basuki Cahaya Purnama's attitude is very powerful. In addition, the findings of deontic-command modality or dominant command-relational epistemic modality coupled with modality of certainty epistemic in the second place indicates that Basuki Cahaya Purnama in tackling the case of Kalijodo, he applied a strict instructions approach without any doubt.

Keywords: Analysis of modality, Basuki Cahaya Purnama's utterances, Kalijodo discourse 


\section{Pendahuluan}

Basuki Cahaya Purnama atau masyarakat mengenalnya dengan sebutan Ahok adalah gubernur DKI Jakarta saat ini. Basuki Cahaya Purnama (selanjutnya disebut Ahok) sebagai gubernur Jakarta telah cukup banyak membuat berbagai perubahan. Contohnya pembersihan kawasan permukiman kumuh di bantaran sungai Ciliwung, atau membersihkan dan menertibkan kawasan pasar Senen dari para pedagang yang berjualan di bahu jalan. Dua bulan terakhir ini, masyarakat Jakarta khususnya dan masyarakat Indonesia umumnya terarah perhatiannya pada wacana penertiban di kawasan permukiman Kalijodo. Alasan yang menjadi perhatian masyarakat terhadap wacana tersebut karena kawasan Kalijodo berada di daerah Ibu kota negara sekaligus kawasan yang dikenal sebagai kawasan pelacuran dan perjudian.

Wacana Kalijodo yang menjadi pemberitaan nasional tersebut menimbulkan berbagai opini, sanggahan, dukungan, ataupun pendapat-pendapat lainnya bertebaran di berbagai media, tidak terlepas pernyataanpernyataan Ahok sebagai Gubernur DKI Jakarta dalam menyikapi wacana tersebut. Pernyataan Ahok tersebut tidak terlepas dari penggunaan bahasa sebagai sarana komunikasi. Sebagaimana yang dikemukakan Halliday (Santoso, 2012:84-88) bahwa bahasa dapat berfungsi sebagai alat komunikasi, alat ekspresi, dan alat kontrol sosial.

Masyarakat sebagian mengenal Ahok sebagai pemimpin yang tegas, namun ada pula masyarakat yang menilai kepemimpinan Ahok kurang santun dan arogan. Penilaian tersebut merupakan penilaian masyarakat terhadap berbagai pernyataan Ahok sebagai gubernur dalam berbagai kesempatan. Sejatinya setiap tuturan pernyataan selalu merepresentasikan sikap dan tindakan seseorang dalam hal ini seorang pejabat

Berdasarkan paparan di atas peneliti menilai bahwa tuturan pernyataan Ahok dalam wacana Kalijodo merupakan data yang sangat strategis untuk dianalisis secara linguistik khususnya analisis modalitas, mengingat dua alasan: Pertama, Ahok merupakan tokoh yang telah dikenal secara nasional dan berbagai tuturan pernyataannya menimbulkan banyak kontroversi. Kedua, wacana Kalijodo merupakan wacana yang sangat merepresentasikan keadaan sosial yang aktual di masyarakat.

Adapun analisis modalitas sebagai pisau analisis dalam penelitian ini bertumpu pada pengklasifikasian modalitas bahasa Indonesia menurut Alwi (1992) ditambah dengan pengertian modalitas yang dikemukakan Fairclough (2003: 164-165) yang menyatakan bahwa modalitas merepresentasikan pendirian (stance) serta ketertarikan atau keterkaitan (affinity) pembicara atau penulis kepada seseorang atau sesuatu yang terungkap dalam klausa. Dengan kata lain analisis modalitas pada penelitian ini bertujuan untuk mengetahui sikap apa yang terepresentasi dari tuturan pernyataan Ahok dalam wacana Kalijodo.

Penelitian modalitas sudah banyak dilakukan di antaranya analisis modalitas terhadap pidato Susilo Bambang Yudoyono (SBY) yang dilakukan Halimatussakdiah pada tahun 2010. Hasilnya bersimpulan bahwa SBY menunjukkan posisi yang tidak lebih tinggi dari pendengarnya karena terdapat kekhawatiran dan keraguan. Pada tahun 2013 peneliti sendiri telah melakukan penelitian analisis modalitas yang ada di pemberitaan media Sindonews.com berkait wacana Miss World 2013. Hasil analisis menunjukkan bahwa media Sindonewas.com merepresentasikan peristiwa Miss World sebagai peristiwa yang akan menguntungkan Indonesia dan harus diapresiasi masyarakat. Selain itu, Darmayanti dkk. (2011) Juga meneliti modalitas Susilo Bambang Yudoyono dalam pidatonya sebagai calon presiden 20092014. Hasil penelitian Darmayanti dkk. Merumuskan bahwa dalam pidato tersebut terdapat beberapa bentuk modalitas dapat dan bisa yang menandakan SBY berupaya menempatkan pidatonya sebagai alat promosi diri dan bukan untuk alat paksaan. Sementara itu, analisis modalitas terhadap tuturan Ahok khususnya dalam wacana Kalijodo sepengetahuan peneliti belum ada yang meneliti, oleh karena itu penelitian ini menarik untuk diteliti mengingat wacana Kalijodo telah menjadi isu dan wacana nasional yang banyak diperbincangkan masyarakat. 
Berdasarkan latar belakang di atas masalah penelitian ini adalah bentuk-bentuk modalitas dalam tuturan Ahok dan sikap serta representasi Ahok sebagai gubernur terhadap wacana Kalijodo. Adapun tujuan penelitian ini adalah untuk mengetahui bentuk modalitas apa saja yang terdapat dalam tuturan Ahok dan untuk mengetahui sikap serta representasi Ahok dalam wacana Kalijodo.

\section{Teori dan Metode}

\subsection{Modalitas dan Linguistik Sistemik Fungsional}

Modalitas menurut Bally (Alwi 1992: 2) adalah bentuk bahasa yang menggambarkan penilaian berdasarkan nalar, penilaian berdasarkan rasa, atau keinginan pembicara sehubungan dengan persepsi atau pengungkapan jiwanya. Sementara itu, dinyatakan oleh Hodge dan Kress (Fairclough, 2003: 165-166) bahwa modalitas merepresentasikan pendirian (stance) dan ketertarikan atau keterkaitan (affinity) pembicara atau penulis kepada seseorang atau sesuatu yang terungkap dalam suatu ungkapan (utterance). Hal tersebut dapat disimpulkan bahwa yang dinamakan modalitas merupakan penanda yang merepresentasikan sikap atau penilaian seseorang terhadap seseorang ataupun sesuatu hal. Menurut Alwi (1992: 5) sikap pembicara yang dimaksudkan pada rumusan modalitas itu sejalan dengan pandangan Halliday (Sinar, 2012: 44-45) mengenai fungsi interpersonal bahasa. Pemenuhan fungsi interpersonal bahasa ini terlihat pada seseorang (sebagai pembicara) yang berhubungan atau berkomunikasi dengan orang lain yang menjadi pendengar (hearer), tersapa (addressee), atau teman bicara (inter-locutor)-nya. Fungsi interpersonal tersebut menekankan adanya hubungan apik antara produsen wacana dengan pengonsumsi wacana. Dalam hal ini, apapun makna bahasa yang ditangkap pembacapendengar dari suatu wacana akan menjadi telaah bahasa dalam fungsinya sebagai sarana interpersonal. Selain itu, fungsi interpersonal tersebut tidak dapat dipisahkan dari fungsi bahasa sebagai instrumental. Linguistik instrumental merupakan kajian bahasa untuk mengetahui sesuatu di luar bahasa (Santoso, 2012: 63-64).
Selain yang disampaikan Alwi (1992) tersebut pembicaraan modalitas juga berkait dengan fungsi bahasa sebagai alat kontrol sosial. Sebagaimana yang telah dirumuskan Halliday (Sinar, 2012: 22) bahwa fungsi bahasa salah satunya sebagai alat kontrol sosial. Jika tadi modalitas merupakan penanda yang merepresentasikan sikap atau penilaian terhadap seseorang sebagai lawan bicaranya maka dalam hal ini modalitas yang berkait dengan fungsi kontrol sosial adalah ketika sikap atau penilaian terhadap suatu realitas atau peristiwa.

Sejalan dengan itu, analisis modalitas merupakan bagian dari teori linguistik sistemik fungsional. Teori linguistik Sistemik Fungsional selanjutnya disingkat (TLSF) memandang penggunaan bahasa sebagai fenomena sosial, yaitu bahasa mempunyai hubungan dengan struktur sosial dikaitkan dengan struktur sosial bahasa cenderung sebagai alat berbuat (doing) sesuatu daripada mengetahui (knowing) sesuatu di dalam suatu sistem jaringan yang terdiri atas pilihan-pilihan arti (Sinar, 2012:20). Hal tersebut dapat dimaknai bahwa TLSF memandang bahasa yang selalu memiliki fungsi tertentu berdasarkan konteks sosialnya. Jadi, setiap bahasa tidak dapat dimaknai tanpa melihat konteks sosialnya.

\subsection{Jenis-Jenis Modalitas}

Menurut Santoso (2012: 157) modalitas adalah fitur lingual yang menunjukkan tingkat komitmen atau sikap penutur terhadap proposisi yang mereka tuturkan atau sikap terhadap pendengar. Berbagai modal dalam bahasa tertentu dapat menginformasikan tingkat komitmen dan sikap penutur. Berkaitan dengan itu, dinyatakan oleh Fairclough (Santoso, 2012: 157) bahwa modalitas ditinjau dari nilai fiturnya terdapat dua jenis, yakni modalitas relasional dan ekspresif. Modalitas relasional adalah persoalan autoritas satu partisipan dalam hubungan dengan partisipan lainnya. Kajian terhadap pelbagai modal akan memberikan informasi tentang 'keinginan', 'harapan', pembiaran, permintaan, ajakan, kemungkinan, keharusan, kepastian, perintah, izin, larangan, dan kemampuan atau kesanggupan. Modalitas ekspresif adalah modalitas yang digunakan untuk menunjukkan autoritas penghasil teks 
yang berkenaan dengan kebenaran atau kemungkinan representasi realitas. Dalam modalitas ini terkandung makna 'kemungkinan' , izin, kepastian, kewajiban, termasuk juga di dalamnya 'ketidakmungkinan'. Alwi (1992: 233) dalam penelitiannya terhadap modalitas bahasa Indonesia menyatakan bahwa modalitas dapat dibagi menjadi empat macam. Pertama, modalitas intensional, yakni modalitas yang digunakan untuk menyatakan sikap penutur sehubungan dengan peristiwa yang diungkapkannya. Modalitas ini berkaitan dengan fungsi instrumental bahasa. Kedua, modalitas epistemik, yakni modalitas yang merupakan penilaian penutur terhadap kemungkinan dan keperluan bahwa sesuatu itu demikian atau tidak demikian. Ketiga, modalitas deontik, yakni modalitas yang berhubungan dengan kewajiban atas dasar kewenangan pribadi atau kewenangan resmi. Keempat, modalitas dinamik, yakni modalitas yang mempersoalkan sikap pembicara terhadap aktualisasi peristiwa yang ditentukan oleh peri keadaan yang lebih bersifat empiris. Yang menjadi tolok ukur pembicara dalam modalitas dinamik adalah hukum alam, sementara itu modalitas deontik adalah kaidah sosial.

Sementara menurut Saragih (2006) bentuk-bentuk modalitas dapat diklasifikasi berdasar derajat nilainya.

Tabel Jenis dan Nilai Modalitas (Saragih, 2006 dalam Halimatuksakdiah (2010: 32)

\begin{tabular}{|l|l|l|l|l|}
\hline Modalitas & \multicolumn{4}{|c|}{ Polar Positif } \\
\hline & Probabilitas & Keseringan & Keharusan & Kecenderungan \\
\hline Tinggi & Pasti & Selalu & Wajib & Ditetapkan \\
\hline Menengah & Mungkin & Bisa & Diharapkan & Mau \\
\hline Rendah & Barangkali & Kadang-kadang & Boleh & Ingin \\
\hline \multicolumn{5}{|r|}{ Polar Negatif } \\
\hline
\end{tabular}

Dapat dirumuskan bahwa pembagian modalitas menurut Saragih merupakan pembagian modalitas menurut derajat nilainya baik yang bersifat probabilitas, keseringan, keharusan, maupun kecenderungan. Konsekuensi dari pemakaian setiap modalitas tersebut akan merepresentasikan sikap dan derajat kuasa penuturnya. Adapun yang dimaksud polar positif menunjuk pada jenis modalitas yang berada di baris atas seperti pasti, selalu, wajib, ditetapkan, sedangkan yang berpolar negatif menunjuk pada modalitas yang berada di baris bawah, seperti barangkali, kadang-kadang, boleh, dan ingin.

\section{Metode Penelitian}

Pada dasarnya, penelitian ini beranjak dari pernyataan Mc Guigan yang dikembangkan kembali oleh Mahsun (2014:5) bahwa masalah penelitian itu dimungkinkan muncul atas tiga keadaan: (1) adanya informasi yang mengakibatkan munculnya kesenjangan dalam pengetahuan,; (2) adanya hasil-hasil penelitian yang bertentangan; (3) adanya suatu kenyataan dan kita bermaksud menjelaskannya melalui penelitian. Peneliti berkeyakinan bahwa alasan pertama dan ketigalah yang menjadi kendali dalam penelitian ini. Untuk dapat melakukan penelitian yang ilmiah, penelitian harus dilakukan melalui prosedur dan sistematika yang jelas. Hal itu di antaranya dilakukan melalui penentuan metodologi dan teknik penelitian. Berikut metode penelitian yang digunakan dalam penelitian ini.

Penelitian ini merupakan penelitian kualitatif-deskriptif. Sumber data dalam penelitian ini adalah cuplikan-cuplikan tuturan Ahok dalam pemberitaan di media televisi yang terekam dalam situs youtube.com. Setiap cuplikan ditranskripsi dan diklasifikasi berdasarkan jenis modalitas. Sementara data yang dijadikan objek penelitian adalah berbagai 
jenis modalitas yang ada dalam tuturan Ahok. Untuk menilai reliabilitas data digunakan teknik trianggulasi data, yakni dengan cara membandingkan muatan antardata, apakah saling berkaitan atau tidak. Selain itu, teknik trianggulasi data juga dilakukan dengan cara data tersebut dinilai oleh beberapa responden, apakah data tersebut relevan atau tidak dengan tujuan penelitian. Instrumen dalam penelitian ini adalah peneliti sendiri, yakni sebagai penganalisis dan penafsir data dengan pendekatan analisis modalitas dalam wacana. $\$

\section{Pembahasan}

\subsection{Hasil Temuan}

\section{A. Trakripsi sumber data 1:}

Judul: Ahok Tak Main-Main Relokasi Warga Kalijodo.

Dicuplik oleh KompasTV

Alamat URL:

https://www.youtube.com/watch?v=hBfnlqhz8 Uw

Ahok :"Kirim peringatan 1,2, dan 3; nah walikota merasa perlu pendekatan dulu, kalau mereka ga mau pendekatan ya kita kirim 1, 2, dan 3."

Wartawan: "Lebih berat dari tanah abang pak?"

Ahok : "Kalau kamu bilang bentrok ya kamu pasti akan bentrok, orang dudukin sungai aja ga terima kok, apalagi sumber duit, kalau betul di situ ada perjudian itu perputaran uangnya besar, itu kalau betul ada perjudian ya, berarti ada oknumoknum yang terlibat, pasti ada perlawanan, nah kalau perlawanan saya serahkan nanti ada Protabnya kok, kalau kamu melawan itu ada protabnya kok. Aparat itu ada protabnya kok iya kan!. Kita sih siap."

Wartawan:“...” (jeda)

Ahok :"Iya pokoknya saya tak tergantung walikota, kalau walikota ga berani harus kita ganti."

\section{Temuan:}

Bentuk modalitas yang ditemukan pada sumber data 1 adalah sebagai berikut. Pertama, kirim peringatan... merupakan bentuk modalitas deontik bermakna perintah. Kedua, Pasti akan bentrok. adanya penanda modalitas pasti merupakan jenis modalitas epistemik kepastian. Modalitas pasti merepresentasikan sikap Ahok yang meyakini kalau bentrok akan terjadi antara aparat dan masyarakat di Kalijodo; Ketiga, Pasti ada perlawan. Modalitas pasti dalam klausa "...pasti ada perlawanan, nah kalau perlawanan saya serahkan, nanti ada Protabnya kok...", tuturan itu merepresentasikan keyakinan akan terjadi perlawanan anatara aparat yang menertibkan dengan masyarakat Kalijodo; Keempat, kita sih siap, modalitas siap dapat dikategorikan sebagai modalitas dinamik yang berkaitan dengan kesanggupan. Kesanggupan yang diucapkan Ahok dipengaruhi dan diakibatkan oleh proses sosial, dalam hal ini Ahok sebagai Gubernur Jakarta memilki kuasa untuk siap menghadapi perlawan warga Kalijodo. Kelima, harus kita ganti. Modalitas harus dapat dikategorikan dalam jenis modalitas deotik perintah.

\section{B. Transkripsi sumber data 2}

Judul: Preman Kalijodo Tantang FPI dan Ahok "Serbu Kalijodo" (Heboh)

Dicuplik oleh MetroTV

Alamat URL:

https://www.youtube.com/watch?v=oc7lyKLLj YE

Ahok :"Saya berpikir kalau dibiarindibiarin terus nanti korban lagikorban lagi ni, yaudahlah kita utamakan bersihin dululah Kalijodo."

Wartawan: "Pemprov ada kendala ga sih, Pak, kan katanya preman di sana seremserem, Pak!"

Ahok : "Ya mana ada sih negara kalah kalah sama preman."

Wartawan: "Tetapi berkali-kali penertiban Kapolsek sering ditodong pistol gitu, Pak terus."

Ahok : "Ya jangan 1,2 orang, datangnya pasukan dong kalau dianya ada seribu, kita kirim seribu brimob sejata lengkap kok."

Wartawan:"Tapi udah ada koordinasinya belum sih, Pak, sama polisi yang lain?” 
Ahok :"Nanti kan udah SP1 SP2 SP 3 baru kita minta bantuan polisi."

\section{Temuan:}

Pertama, dalam penggalan nanti korban lagikorban lagi ni di sini terdapat modalitas nanti dapat dikategorikan sebagai bentuk modalitas epistemik kemungkinan. Kedua, dalam penggalan ... kita utamakan bersihin dululah kalijodo... dalam penggalan tersebut terdapat penanda modalitas bersihin, klausa tersebut mengandung modalitas deontik perintah. Ketiga, dalam klausa $\mathrm{Ya}$ jangan 1,2 orang , datangnya pasukan dong... terdapat penanda modalitas ya jangan, modalitas dapat dikategorikan sebagai modalitas deontik perintah. Selanjutnya keempat terdapat modalitas kita kirim seribu brimob yang juga berkategori deontik perintah. Kelima, pada penggalan kita minta bantuan polisi... terdapat penanda modalitas minta yang dapat dikategorikan sebagai modalitas intensional permintaan.

\section{Transkripsi Sumber Data 3}

Judul: Perintah Tegas Ahok-Bersihkan Kalijodo, karena lebih banyak mudharatnya (sarang pelacuran dan miras)

Dicuplik oleh media televisi Berita Satu

Alamat URL:

https:/www.youtube.com/watch? $v=$ hcoArVLt

$\mathrm{Yds}$

Wartawan:"Nah Pak kemaren ada Fortuner dari Kalijodo nah itu peredaran miras dan prostitusi bagaimana, Pak?

Ahok :"Makanya saya sudah bilang Kalijodo harus segera sosialisasi, kita bersihkan semua ga ada toleransi, lebih banyak mudarat daripada manfaat itu.

\section{Temuan:}

Dalam sumber data 3 hanya ditemukan dua penanda modalitas, yakni modalitas harus dan ga ada. Modalitas harus yang terdapat dalam penggalan harus segera sosialisasi dapat dikategorikan sebagai modalitas deontik perintah. Selanjutnya modalitas yang ditemukan, yakni terdapat modalitas ga ada dapat dikategorikan sebagai modalitas epistemik kepastian.

\section{Transkripsi sumber data 4}

Judul: Tutup Kalijodo, Ahok Semprot Wartawan

Dicuplik oleh MetroTV

Alamat URL:

https://www.youtube.com/watch?v=GRoZWkK $6 \mathrm{Dgg}$

Ahok :"Ee, dari Polisi dan TNI sudah menggelar pasukan sosialisasi, kita akan sisir tutup dulu, jadi pintu masuk situ kita tutup dulu nih, biar pelanggannya ga ada yang dateng, jadi, orang yang di luar KTP sana ga boleh masuk sana aja jam malem,

Wartawan: "Kapan?"

Ahok : “Udah jalan”... (jeda)

"Dalam sistim pokok Undang-undang Agraria, disebutkan bahwa namanya PBB itu bukan sebagai tanda milik, trus kalau kamu duduikin tanah negara, itu salah, itu bisa pidana, apalagi kamu dudukin tanah negara disewakan ke orang, dimanfaatkan buat bisnis itu pidana.

\section{Temuan:}

Ditemukan empat bentuk modalitas dalam sumber data 4. Pertama, kita akan sisir tutup dulu, penanda modalitas akan dalam penggalan tersebut dapat dikategorikan seagai modalitas epistemik kepastian. Kedua, kita tutup dulu nih, mengandung modalitas deontik perintah. Ketiga, ga boleh masuk sana... penanda modalitas ga boleh dalam penggalan tersebut berkategori modalitas deontik perintah. Keempat, terdapat modalitas epistemik kepastian, yakni penanda modalitas bisa pada penggalan itu salah, itu bisa pidana.

Tabel Rekapitulasi Temuan Modalitas Tuturan Ahok dalam Wacana Kalijodo

\begin{tabular}{|l|l|l|l|}
\hline No. & Bentuk Modalitas & Penggalan Kalimat & Jenis modalitas (Alwi 1990) \\
\hline 1 & kirim & Kirim peringatan 1,2, dan 3 & Deontik perintah \\
\hline 2 & pasti akan & pasti akan bentrok & Epistemik kepastian \\
\hline
\end{tabular}




\begin{tabular}{|l|l|l|l|}
\hline 3 & pasti & pasti ada perlawan. & Epistemik kepastian \\
\hline 4 & siap & kita sih siap & Dinamik kesanggupan \\
\hline 5 & harus & harus kita ganti & Deontik perintah \\
\hline 6 & nanti & lagi & Epistemik keteramalan \\
\hline 7 & bersihin & $\begin{array}{l}\text { kita utamakan bersihin } \\
\text { dululah kalijodo }\end{array}$ & Deontik perintah \\
\hline 8 & jangan & ya jangan 1,2 orang & Deontik perintah \\
\hline 9 & kirim & kirim seribu brimob & Deontik perintah \\
\hline 10 & minta & kita minta bantuan polisi & Intensional permintaan \\
\hline 11 & harus & harus segera sosialisasi & Deontik perintah \\
\hline 12 & ga ada & ga ada toleransi & Deontik perintah \\
\hline 13 & akan & kita akan sisir & Epistemik kepastian \\
\hline 14 & tutup dulu & kita tutup dulu nih & Deontik perintah \\
\hline 15 & ga boleh & ga boleh masuk sana & Deontik perintah \\
\hline 16 & itu bisa & itu salah, itu bisa pidana & Epistemik kepastian \\
\hline
\end{tabular}

\subsection{Pembahasan Hasil Temuan}

Temuan modalitas yang didapatkan dari hasil analisis pada subbab sebelumnya didapatkan terdapat enam belas bentuk modalitas. Enam belas bentuk modalitas tersebut jika ditinjau dari jenis modalitas menurut pembagian Alwi (1992) terdiri atas empat modalitas epistemik yang bermakna kepastian; sembilan modalitas deontik bermakna perintah; satu bentuk modalitas dinamik kesanggupan; dan satu bentuk modalitas intensional permintaan.

Dalam tinjauan Fairclough ( Santoso, 2012: 157) modalitas dapat ditinjau dari nilai fiturnya. Nilai fitur tersebut dapat dibagi menjadi dua kategori, yakni: modalitas relasional dan modalitas ekspresif. Berikut tabel klasifikasi modalitas tuturan Ahok berdasarkan teori Fairclough (2012).

\begin{tabular}{|l|l|l|l|c|}
\hline No. & Bentuk Modalitas & Penggalan Kalimat & \multicolumn{2}{l|}{ Jenis Modalitas (Fairclough 2012) } \\
\cline { 4 - 5 } & & & Relasional & Ekspresif \\
\hline 1 & kirim & Kirim peringatan 1,2, dan 3 & $\mathrm{V}$ (perintah) & \\
\hline 2 & pasti akan & pasti akan bentrok & & $\mathrm{V}$ (kepastian) \\
\hline 3 & pasti & pasti ada perlawan. & $\mathrm{V}$ (kepastian) \\
\hline 4 & siap & kita sih siap & (Kesanggupan) & \\
\hline 5 & harus & harus kita ganti & $\mathrm{V}$ (perintah) & \\
\hline
\end{tabular}




\begin{tabular}{|c|c|c|c|c|}
\hline 6 & nanti & nanti korban lagi-korban lagi & $\begin{array}{c}\mathrm{V} \\
\text { (kemungkinan) }\end{array}$ & \\
\hline 7 & bersihin & $\begin{array}{l}\text { kita utamakan bersihin dululah } \\
\text { kalijodo. }\end{array}$ & $\checkmark$ (perintah) & \\
\hline 8 & jangan & ya jangan 1,2 orang & $\checkmark$ (perintah) & \\
\hline 9 & kirim & kirim seribu brimob & $\checkmark$ (perintah) & \\
\hline 10 & minta & kita minta bantuan polisi & $\checkmark$ (permintaan) & \\
\hline 11 & harus & harus segera sosialisasi & $\checkmark$ (perintah) & \\
\hline 12 & ga ada & ga ada toleransi & $\checkmark$ (perintah) & \\
\hline 13 & akan & kita akan sisir & V (kepastian) & \\
\hline 14 & tutup dulu & kita tutup dulu nih & $\sqrt{ }$ (perintah) & \\
\hline 15 & ga boleh & ga boleh masuk sana & $\checkmark($ perintah) & \\
\hline 16 & itu bisa & itu salah, itu bisa pidana & & $\boldsymbol{V}$ (kepastian) \\
\hline
\end{tabular}

Terdapat tiga belas bentuk modalitas relasional dalam tuturan Ahok dengan rincian tujuh modalitas relasional perintah. Kemudian terdapat masing-masing satu modalitas relasional-kesanggupan, relasional-permintaan, dan relasional-kepastian. Hasil temuan di atas merepresentasikan bahwa Ahok dalam hal ini ketika dalam wawancara dengan wartawan memosisikan dirinya sebagi seseorang yang memiiki kuasa penuh. Hal itu ditunjukkan oleh temuan modalitas deontik-perintah maupun relasional-perintah yang dominan. Modalitas seperti harus, jangan dan ga boleh itu memiliki derajat nilai kuasa yang tinggi. Dibandingkan dengan penelitian modalitas yang dilakukan Darmayanti dkk. (2011) terhadap pidato Susilo Bambang Yudoyono (selanjutnya disebut SBY) sebagai calon presiden, modalitas Ahok memiliki derajat kuasa lebih tinggi dibanding SBY. Hal itu, dapat dimaklumi karena modalitas yang ditemukan Darmayanti dkk. Pada pidato SBY tersebut merupakan dalam konteks sebagai calon presiden dan bukan sebagai presiden. Akan tetapi, lemahnya derajat kuasa SBY yang ditunjukkan dalam pidato tersebut juga didapatkan oleh penelitian Halimatussakdiah yang menyatakan SBY menunjukkan posisi yang tidak lebih tinggi dari pendengarnya karena terdapat kekhawatiran dan keraguan dalam sebuah pidatonya sebagai presiden.

Bentuk modalitas seperti: pasti akan bentrok, pasti ada perlawanan, itu salah, merupakan modalitas ekspresif. Klausa Pasti akan bentrok dan pasti akan ada perlawanan merepresentasikan ekspresi Ahok terhadap realitas dalam hal ini penertiban warga Kalijodo. Ahok memiliki keyakinan yang tinggi terhadap apa yang akan terjadi jika proses penertiban dilaksanakan. Sementara itu, frasa itu salah dalam penggalan itu salah, itu bisa pidana merepresentasikan ekspresi Ahok yang yakin menilai bahwa apa yang dilakukan warga Kalijodo yang mengomersialkan tanah negara merupakan bentuk kejahatan pidana. Penjelasan tersebut menunjukkan bahwa Ahok memiliki sikap yang begitu yakin akan keyakinan yang diyakininya terkait realitas masyarakat Kalijodo serta rencana penertibannya.

Dibandingkan dengan modalitas pada pidato SBY yang diteliti Halimatusakdiah (2010), modalitas SBY secara ekspresif menunjukkan kekurang-yakinan sedangkan Ahok sebaliknya menunjukkan sikap yang yakin. Derajat kuasa Ahok yang tinggi itu juga diperkuat dengan bentuk modalitas dinamik kesanggupan, seperti pada penggalan kita sih siap. Hal itu menunjukkan kesanggupan 
Ahok untuk dapat menertibkan warga Kalijodo. Kesanggupan Ahok tersebut dapat dimaknai bahwa dirinya merupakan seorang gubernur yang mampu menyelesaikan masalah termasuk penertiban warga Kalijodo.

\section{Penutup}

\subsection{Simpulan}

Hasil temuan dan pembahasa menunjukkan terdapat sembilan bentuk modalitas deontik bermakna perintah dan atau sembilan modalitas relasional-perintah. Jumlah modalitas tersebut sangat dominan dibanding dengan jumlah modalitas epistemik bermakna kepastian empat buah, modalitas dinamik kesanggupan satu buah, modalitas epistemik keteramalan satu buah, dan modalitas intensional permintaan satu buah. Hal tersebut merepresentasikan sikap Ahok yang sangat memiliki kuasa.

Selain itu, temuan modalitas deontikperintah atau relasional-perintah yang dominan ditambah dengan modalitas epistemik kepastian diurutan kedua jumlahnya, menunjukkan bahwa Ahok dalam menanggulangi kasus Kalijodo dengan pendekatan perintah. Sikap yang tegas dan tanpa keraguan juga tampak dari penggunaan modalitas epistemik bermakna kepastian.

\subsection{Saran}

Berdasarkan hasil temuan dan pembahasan penelitian ini, penulis menyarankan agar penelitian ini dilanjutkan dalam skala yang lebih besar, misalnya analisis modalitas ini dikembangkan ke arah kajian analisis wacana kritis. Dengan mengembangkan teori atau pendekatan analisis wacana kritis maka akan terjawab juga alasan-alasan sosiokultural yang melatarbelakangi penggunaan modalitas oleh Ahok dalam wacana Kalijodo.

\section{Daftar Pustaka}

Ahmadi, Yusep F. 2013. "Representasi Kontes Miss World 2013 di Media Sindonews. Com: Suatu Analisis Wacana Kritis".
Dalam Prosiding Seminar Internasional Studi Bahasa dari Berbagai Perspektif dalam Rangka memperingati Ulang Tahun ke-80 Prof. Dr. Soepomo Poejosoedarmo. Universitas Gajah Mada.

Alwi, Hasan. 1992. Modalitas dalam Bahasa Indonesia. Yogyakarta: Penerbit Kanisius

Darmayanti, Nani, dkk. 2011. Pidato Politik Susilo Bambang Yudoyono sebagai Calon Presiden Republik Indonesia 2009-2014: 2014. Jurnal Metalingua Vol. 9, No. 1, hlm.: 73-88.

Fairclough, Norman. 1989. Language and Power. New York: Longman Group UK Limited.

Fairclough, Norman. 2003. Analysing Discourse: Textual Analysis for Social Research. London \& New York: Routledge Halimatussakdiah. 2010. Wacana Kepemimpinan: Analisis Fase Dan Modalitas Teks Pidato Presiden Susilo Bambang Yudhoyono Berdasarkan Perspektif Linguistik Sistemik Fungsional. Tesis. Sekolah Pascasarjana Universitas Sumatera Utara.

Santoso, Anang. 2012. Studi Bahasa Kritis: Menguak Bahasa Membongkar Kuasa. Bandung: CV. Mandar Maju.

Sinar, Silvana T. 2012. Teori dan Analisis Wacana: Pendekatan Linguistik SistemikFungsional. Medan: Mitra Medan.

Mahsun, M.S. 2014. Metode Penelitian Bahasa: Tahapan Strategi, Metode, dan Tekniknya. Jakarta: Rajawali Pers.

\section{Sumber Internet}

Halimatussakdiah. $\quad 2010 . \quad$ "Wacana Kepemimpinan: Analisis Fase Dan Modalitas Teks Pidato Presiden Susilo Bambang Yudhoyono Berdasarkan Perspektif Linguistik Sistemik Fungsional". Tesis. Sekolah Pascasarjana Universitas Sumatera Utara. Tersedia dalam laman: http://repository.usu.ac.id/xmlui/handle/12 $3456789 / 19368$ ?show=full diakses januari 2016 . 